\title{
Relationship between Psychological Well-Being and Smartphone Addiction of University Students
}

\author{
Assoc. Prof. Hatice Kumcağiz ${ }^{1} \&$ Asst. Prof. Yüksel Gündüz ${ }^{2}$ \\ ${ }^{1}$ Division of Psychological Counseling and Guidance, Department of Educational Sciences, Faculty of Education, \\ Ondokuz Mayıs University. \\ ${ }^{2}$ Division of Educational Administration, Supervision, Planning and Economics, Department of Educational \\ Sciences, Faculty of Education, Ondokuz Mayıs University. \\ Correspondence: Assoc. Prof. Hatice Kumcağiz, Ondokuz Mayıs University, Faculty of Education, Division of \\ Psychological Counseling and Guidance, Department of Educational Sciences, Samsun, Turkey. Tel: \\ 90-362-3121-9191/ 5375
}

Received: September 17, 2016

Accepted: October 11, 2016

Online Published: October 13, 2016

doi:10.5430/ijhe.v5n4p144

URL: http://dx.doi.org/10.5430/ijhe.v5n4p144

A part of this study was presented as an oral paper at the International Dynamic, Explorative and Active Learninig Conference II hold on September 1 to 3, 2015 in Samsun.

\begin{abstract}
This study was carried out to examine the relationship between university students' levels of psychological well-being and smartphone addiction. The study group consists of a total of 408 students ( 303 female and 105 male) selected by random sampling method and studying at the departments of Primary Education, Science Teaching, Art and Crafts Teaching, French Teaching, and Guidance and Psychological Counseling at the Faculty of Education, Ondokuz Mayis University in the 2015-2016 academic year. In this research, the Psychological Well-Being Scale, Smartphone Addiction Scale-Short Version, and Personal Information Form were used to collect data.The independent-samples t-test, arithmetic mean, one-way analysis of variance (ANOVA) and Scheffé's post hoc test were employed for the analysis and interpretation of data. The Pearson Product-Moment Correlation Coefficient was used for the relationship between the level of psychological well-being and the use of smartphones, and accordingly the results were evaluated.The relationship between university students' levels of psychological well-being and smartphone addiction seems to be significant based on this research. Factors affecting university students' levels of psychological well-being and smartphone addiction include gender, grade, parental attitudes, economic status of the family, and level of perception.
\end{abstract}

Keywords: Smartphone, Cell phone, Psychological well-being, University students

\section{Introduction}

The World Health Organization defines health as a state of complete physical, mental and social well-being and not merely the absence of disease or infirmity (Kesgin \& Topuzoğlu, 2006). Based on this definition, it is necessary to maintain a favorable balance between physical, mental and social states in order to ensure complete well-being. It has an important role in changing individual's well-being in a positive or negative way that an individual turn their decisions into action during the lifetime. Considering that the positive maintenance of well-being makes individuals happy, researchers have started to investigate other potential factors that may influence happiness (Saygin \& Arslan, 2009; Osmanoğlu \& Kaya, 2013, Eryılmaz, 2010). "Psychological well-being" was formerly stated as the absence of negative psychological traits such as depression, anxiety, and anger; however, the perspective on the term has changed over time (Y1lmaz, 2013).

Psychological well-being has been associated with a positive understanding and positive social relationships (Akın, 2009). In other words, psychological well-being can be defined as the ability of a person to express his complacency without allowing others to affect the positive feelings he experiences (Diener et al., 2003). Psychological well-being is closely related to self-acceptance, positive relations with others, autonomy, environmental mastery, purpose in life, and personal growth besides healthy physiology without stress and other mental problems (Ryff, 1989). Ryff's psychological well-being theory is based on the concepts in developmental psychology and clinical psychology. As 
the absence of disease is not an evidence for psychological well-being so it is not a positive indicator of for personal happiness and individual gratification. According to Ryff's psychological well-being theory, psychological well-being depends on individual's positive functioning in some areas of life (Osmanoğlu \& Kaya, 2010). Additionally, the term psychological well-being expresses a broader well-being concept rather than momentary feelings (Uçan \& Kıran-Esen, 2015). Due to the characteristics mentioned above, psychological well-being attracted the attention of many researchers and addressed in a number of research (Seligman \& Csikszentmihalyi, 2000; Ryff, 1989; Çeçen \& Cenkseven, 2007; Tütüncü, 2012). In our age, it is known that there are many variables that affect psychological well-being of individuals, and technological products are one of the most important variables impacting human psychology.

Technology is known to have a substantial influence on human life. In this regard, mass media which is showing a rapid improvement day by day has become one of the most significant information sources in daily life (Çalışkan-Ülkü \& Demir,2013). Smartphones are one of the most important examples of the mass media. Using smartphones holds an important place in everyday business and social life of individuals. Smartphone industry is a market witnessing huge developments and innovations which enable the introduction of new types of smartphones which make life easier with various features including video calls, computer, internet, camera, navigation, music player, calculator, camera, and video-recording. Thanks to these features, smartphones have become an indispensable element of life and their usage has increased day by day (Tatlı, 2015; Doğan \& Karakuş, 2016). As a result, using smartphones has turned into a passion among young people. It has been specified that especially students have a tendency to look at or give attention to their smartphones regardless of the setting. This situation may be interpreted as smartphone-passion or -addiction (Gümüş \& Örgev, 2015).

Smartphones aiming to enrich communication and computing have as many negative effects as positive ones on young people's social behavior, learning skills, achievements and even relationships with the environment. In other words, despite the benefits it has brought to people's lives, this device leads to serious problems depending on its usage in different times and places (Gümüş \& Örgev, 2015). One of the most significant problems caused by smartphone usage is the possibility of behavioral addictions. In the case of behavioral addiction, the person cannot prevent himself from doing the relevant behavior and may show tension and unrest he faces with prohibition (Grant et al., 2010). In that condition, the person cannot control himself and is led to the downfall (Doğan, 2011).

According to data from April 2015, smartphones are available in $96.8 \%$ of Turkish households (TUiK; 2015). In this context, it can be concluded that the use smartphones is spreading rapidly among young people. Considering the generality of smartphone ownership in young people, the issue "how much young people absorb and internalize smartphones" come to the fore. Almost all transactions normally made using electronic media can be carried out faster and easier by smartphones. Due to their smart features, smartphones have become a focus of attraction for young people, and thus, the number of smartphone-users is gradually increasing (Gümüş \& Örgev, 2015; Akın \& Divanoğlu, 2009). Studies have indicated that $60 \%$ of young people are addicted to their phones and $65 \%$ use their phone while spending time with other people (Şenyuva, 2016). According to the Cisco Connected World Technologies Report (CCWTR), $42 \%$ of world's young population and 77\% of Turkey's young population "would feel anxious like part of them was missing" if they could not constantly check their smartphones, and $81 \%$ of the $71 \%$ young population in Turkey stated that they were troubled with the addiction situation (CCWTR, 2012).

Smartphones that have a significant place in the life of young people, particularly university students, affect their daily communication, as well. While some people have their phones accessible all the time, some others prefer to limit their usage. Although the innovations provided through technology enable young people to easily adapt such technologies, researchers report that they greatly impact their daily communications and lifestyles in time (Karaaslan \& Budak, 2012; Chen \& Katz, 2009). As it has been indicated, a healthy society is a society of healthy people. Experiencing problem-fee adolescence is extremely important for both personal and public health (Sarikaya, 2015).

In the recent years, a considerable number of research has been performed to draw attention to common use of smartphones among young people and raise awareness on its negative effects. These researches have indicated that the advancement of mobile phones thanks to technology has brought about significant effects on individuals' social and emotional development (Adriana \& James, 2005; Yılmaz et al., 2015; Bianchi \& Phillips, 2005; Çetin, 2015). These technological tools, which are extremely popular especially in the young generation, have led to changes in lifestyles, differentiation of social interaction styles and also procured them to restrict their lives with the technological world (Y1lmaz et al., 2015).

When considered in this context, although smartphones provide many conveniences to young people's lives, they have the potential to damage their social relationships and complicate life through delays in their academic 
development if as they are not used consciously which consequently deteriorate their psychological well-being. Considering the facts mentioned above besides the increasing prevalence of smartphone usage among young people, we have planned this study to investigate the influence of the use of smartphones on young people's psychological well-being level.

We have come across with studies that separately analyze psychological well-being and smartphone usage in adolescent and adult populations. The use of smartphones which is very common and has become an interesting behavioral addiction type among young people is assumed to have an influence on psychological well-being. We, therefore, believe that our study results can contribute to the literature. As we aim to examine the association between student's psychological well-being and smartphone addiction and potential factors that affect this relation, it is expected that our results will make a significant contribution to the studies for the planning and implementation of preventive psychological counseling services and sustain the psychological well-being of students.

The purpose of this study is to reveal the relation between psychological well-being and smartphone addiction in a population of students studying at the Faculty of Education. Within this scope, answers were sought to the following questions:

1. What is the relation between students' psychological well-being and smartphone addiction?

2. Do students' psychological well-being of and smartphone addiction show a statistically significant difference by gender, grade level, parental attitudes of mother and father, academic achievement, and family economic situation?

\section{Methodology}

\subsection{Research Model}

The relational screening model was used in this research as it was conducted to investigate the relationship between psychological well-being and smartphone addiction of university students' studying at the faculty of education. The relational screening model is a research model aiming to determine the presence and degree of a change between two or multiple variables (Karasar, 2009).

\subsection{Study Group}

The study group consists of a total of 408 students (303 female and 105 male) selected by random sampling method and studying at the departments of Primary Education, Science Teaching, Art and Crafts Teaching, French Teaching, and Guidance and Psychological Counseling at the Faculty of Education, Ondokuz Mayis University in the 2015-2016 academic year.

\subsection{Data Collection Tools}

In this research, the Psychological Well-Being Scale, Smartphone Addiction Scale-Short Version, and Personal Information Form were used to collect data.

\subsubsection{Psychological Well-Being Scale}

The Psychological Well-Being Scale introduced by Diener et al. (2009) to measure multiple facets of psychological well-being from positive relationships of individuals and feeling of adequacy to having a meaningful and purposeful was translated into and adapted Turkish by Telef (2013).

According to the exploratory factor analysis of the scale, the total explained variance was $42 \%$. It shows that the scale has a general factor as in the original version. The factor load of the scale items was calculated to range from 0.54 to 0.76 . In the original version, the explained variance was $53 \%$ and the factor loads ranged between 0.61 and 0.77 (Diener et al., 2010). The fit indexes in the confirmatory factor analysis results indicated that the ratio of chi-square value to the degree of freedom was below $5(92.90 / 20=4.645)$. Other fit indexes were RMSEA $=0.08$, $\mathrm{SRMR}=0.04, \mathrm{GFI}=0.96, \mathrm{NFI}=0.94, \mathrm{RFI}=0.92, \mathrm{CFI}=0.95$ and $\mathrm{IFI}=0.95$. When these results are taken into consideration, the scale may be interpreted to have acceptable fit indexes.

The reliability study of the Psychological Well-Being Scale was performed using the Cronbach's alpha coefficient and the test-retest method, and the Cronbach's alpha coefficient was found .80. According to the results of test-retest, there was a positive and significant relation between the first and second applications of the scale $(\mathrm{r}=.86, \mathrm{p}<.01)$. Considering the Cronbach's alpha coefficient and test-retest reliability study results, the scale can be regarded reliable. Item total correlations of the Psychological Well-Being Scale ranged from 0.41 to 0.63 and T-values were significant ( $\mathrm{p}<.001)$. Item analysis showed that the scale had sufficient distinctive features (Telef, 2013). In the study, the Cronbach's alpha coefficient of the Psychological Well-Being Scale was calculated as 0.87 . 


\subsubsection{Smartphone Addiction Scale (SPAS-SF)}

The Smartphone Addiction Scale- Short Form (SPAS-SF) was developed by Kwon et al. (2013) to measure the risk of smartphone addiction and the Turkish version of the form of introduced by Noyan et al. (2015). The Scale consists of 10 items and evaluated using the 6-point Likert scale. The items are scored from 1 to 6 , and the scale scores ranges from 10 to 60 points.

In the validation analysis of the scale, the Kaiser-Meyer-Olkin (KMO) value was found 0.855 . According to the principal components factor analysis performed depending on the short form, a 10 -item scale explains $46.3 \%$ of the total variance in SPAS-SF scores. Principal components analysis indicated the factor loads of scale items to range from 0.487 to 0.826 . The Cronbach's alpha coefficient found in the reliability study of the scale was 0.867 (Noyan et al., 2015:78-79). In the present study, the Cronbach's alpha coefficient of the Smartphone Addiction Scale was calculated as 0.90 .

\subsubsection{Personal Information Form}

The study used a Personal Information Form developed by the researchers to collect personal information of students participating in the research. This form includes information about gender, grade level, perception of academic achievement level and family income status, and perception of parental attitudes.

\subsection{Procedure}

In order to collect data, necessary permits were obtained from the directors of the departments that were included in the research and accessible. Then the measurement tools were administered to voluntary students in suitable classes by researchers. The data collection procedure was completed in about 20-25 minutes.

\subsection{Data Analysis}

The independent-samples t-test and one-way analysis of variance (ANOVA) were used to determine the relationship between the continuous and discrete variables. Scheffe's Multiple Comparison Test was employed to determine between which groups the significant differences occurred. The Pearson Product-Moment Correlation Coefficient was used to measure the relationship between the continuous variables. The arithmetic mean was used for general perceptions. The significance level was considered to be 0.05 . SPSS 21.0 software was used for statistical analyses.

\section{Results}

\subsection{Socio-demographic Characteristics of Students}

Table 1 shows the socio-demographic characteristics of students participating in the research.

Table 1. Socio-demographic characteristics of students

\begin{tabular}{|c|c|c|c|}
\hline Socio-demographic Characteristics & & $\mathrm{N}(408)$ & $\%$ \\
\hline \multirow[t]{2}{*}{ Gender } & Female & 303 & 74,3 \\
\hline & Male & 105 & 25,7 \\
\hline \multirow[t]{4}{*}{ Grade } & $1^{\text {st }}$ grade & 112 & 27,5 \\
\hline & $2^{\text {nd }}$ grade & 93 & 22,8 \\
\hline & $3^{\text {rd }}$ grade & 106 & 26,0 \\
\hline & $4^{\text {th }}$ grade & 97 & 23,8 \\
\hline \multirow{3}{*}{$\begin{array}{l}\text { Perception of academic achievement } \\
\text { level }\end{array}$} & Low & 24 & 5,9 \\
\hline & Moderate & 287 & 70,3 \\
\hline & High & 97 & 23,7 \\
\hline \multirow[t]{5}{*}{ Perception of family economic status } & Very low & 4 & 1,0 \\
\hline & Low & 32 & 7,8 \\
\hline & Moderate & 216 & 52,9 \\
\hline & High & 149 & 36,5 \\
\hline & Very high & 7 & 1,7 \\
\hline \multirow[t]{4}{*}{ Perception of mothers' attitudes } & Indifferent & 22 & 5,4 \\
\hline & Overprotective & 156 & 38,2 \\
\hline & Democratic & 185 & 45,3 \\
\hline & Authoritarian & 45 & 11,0 \\
\hline
\end{tabular}


Perception of fathers' attitudes

\begin{tabular}{lll} 
Indifferent & 35 & 8,6 \\
\hline Overprotective & 78 & 19,1 \\
\hline Democrat & 207 & 50,7 \\
\hline Authoritarian & 88 & 21,6
\end{tabular}

3.2 Results of the Comparison of the Mean Scores of Psychological Well-Being and Smartphone Addiction by Students' Gender

Table 2 shows the independent-samples t-test results of whether there is a significant difference between psychological well-being and smartphone usage based on students' gender.

Table 2. Independent-samples t-test results of psychological well-being and smartphone addiction scores by gender

\begin{tabular}{llccccc}
\hline & Gender & $\mathrm{N}$ & $\mathrm{X}$ & $\mathrm{Sd}$ & $\mathrm{t}$ & $\mathrm{p}$ \\
\hline \multirow{2}{*}{ Psychological Well-being } & Female & 303 & 42.86 & 7.11 & 2.76 & $.006^{*}$ \\
& Male & 105 & 40.29 & 10.80 & & \\
\hline \multirow{2}{*}{ Smartphone Addiction } & Female & 303 & 28.91 & 10.47 & 1.14 & .252 \\
& Male & 105 & 30.31 & 11.59 & & \\
\hline * $<.05$ & & & & & &
\end{tabular}

As seen in Table 2, the female students' mean score $(\overline{\mathrm{X}}=42.86)$ of psychological well-being is higher than the male students' mean score $(\overline{\mathrm{X}}=40.29)$, and based on the statistical analysis, the psychological well-being levels of students significantly differ by gender $[\mathrm{t}(406)=2.76 ; \mathrm{p}<0.05]$.

The male students' mean score $(\overline{\mathrm{X}}=30.31)$ of smartphone addiction is higher than the female students' mean score $(\overline{\mathrm{X}}=28.91)$; however, there is no statistically significant difference in the smartphone addiction levels of students by gender $[\mathrm{t}(406)=1,14 ; \mathrm{p}>0.05]$.

3.3 One-way ANOVA Results of the Psychological Well-Being and Smartphone Addiction Scores by Students' Grade

Table 3 includes the results of the comparison of the psychological well-being and smartphone addiction scores based on students' grade level.

Table 3. One-way ANOVA results of the psychological well-being and smartphone addiction scores by students' grade

\begin{tabular}{llllllll}
\hline & Source of & SS & df & MS & F & p & $\begin{array}{l}\text { Significant Difference } \\
\text { Scheffe's Test }\end{array}$ \\
\hline Variance & Between Groups & 31.22 & 3 & 10.41 & & & \\
Psychological & Within Groups & 27910.30 & 404 & 69.09 & 0.15 & 0.92 & - \\
& Total & 27941.52 & 407 & & & & \\
\hline Smartphong & Between Groups & 2063.11 & 3 & 687.70 & & & $1^{\text {st }}$ and $3^{\text {rd }}$ grades \\
Addiction & Within Groups & 45180.15 & 404 & 111.83 & 6.15 & $0.00 *$ & $1^{\text {st }}$ and $4^{\text {th }}$ grades \\
& Total & 47243.26 & 407 & & & & \\
\hline
\end{tabular}

$* \mathrm{p}<.01$

As seen in Table 3, there is no significant difference in the students' mean score of psychological well-being by grade level $\left[\left(\mathrm{F}_{(3 ; 407)}=1.15 ; \mathrm{p}>.05\right]\right.$. However, the students' mean score of smartphone addiction significantly differs by grade level $\left[\mathrm{F}_{(3,407)}=6.15 ; \mathrm{p}<0.05\right]$. Scheffe's test indicates that the mean smartphone addiction score of $1^{\text {st }}$ grade students $\left(\overline{\mathrm{X}}_{1}=31.90\right)$ is higher than that of $3^{\text {rd }}\left(\overline{\mathrm{X}}_{3}=26.93\right)$ and $4^{\text {th }}$ graders $\left(\overline{\mathrm{X}}_{4}=27.15\right)$. 
3.4 One-way ANOVA Results of the Psychological Well-Being and Smartphone Addiction Scores by Mother's Parental Attitudes

Table 4 shows the results of the comparison of the psychological well-being and smartphone addiction scores based on mother's parental attitudes.

Table 4. One-way ANOVA results of the psychological well-being and smartphone addiction scores by mother's parental attitudes

\begin{tabular}{|c|c|c|c|c|c|c|c|}
\hline & $\begin{array}{l}\text { Source of } \\
\text { Variance }\end{array}$ & SS & $\mathrm{df}$ & MS & $\mathrm{F}$ & $\mathrm{p}$ & $\begin{array}{l}\text { Significant } \\
\text { Scheffe's Test }\end{array}$ \\
\hline \multirow{3}{*}{$\begin{array}{l}\text { Psychological } \\
\text { Well-being }\end{array}$} & Between Groups & 1679.49 & 3 & 559.83 & 8.61 & $0.00 *$ & \multirow{3}{*}{$\begin{array}{l}\text { Indifferent -overprotective } \\
\text { Indifferent -democratic }\end{array}$} \\
\hline & Within Groups & 26262.03 & 404 & 65.01 & & & \\
\hline & Total & 27941.52 & 407 & & & & \\
\hline \multirow{3}{*}{$\begin{array}{l}\text { Smartphone } \\
\text { Addiction }\end{array}$} & Between Groups & 3656.48 & 3 & 1218.83 & 11.0 & $0.00 *$ & \multirow{3}{*}{$\begin{array}{l}\text { Democratic-overprotective } \\
\text { Democratic-authoritarian }\end{array}$} \\
\hline & Within Groups & 45180.15 & 404 & 107.89 & & & \\
\hline & Total & 47243,26 & 407 & & & & \\
\hline
\end{tabular}

$* \mathrm{p}<.01$

There is a statistically significant difference in the students' mean score of psychological well-being based on their mothers' parental attitudes $\left[\mathrm{F}_{(3 ; 407)}=8.61 ; \mathrm{p}<0.05\right]$. Scheffe's test shows that the mean psychological well-being score of students with mother's indifferent attitude $\left(\overline{\mathrm{X}}_{\text {indifferent }}=34.95\right)$ is higher than that of students with mother's overprotective attitude $\left(\overline{\mathrm{X}}_{\text {protective }}=26.93\right)$ and those with mother's democratic attitude $\left(\overline{\mathrm{X}}_{\text {democratic }}=27.15\right)$.

There is also a statistically significant difference in the students' mean score of smartphone addiction by their mothers' parental attitudes $\left(\mathrm{F}_{(3 ; 407)}=11.30 ; \mathrm{p}<0.05\right)$. Based on Scheffe's test, the mean smartphone addiction score of students with mother's democratic attitude $\left(\overline{\mathrm{X}}_{\text {democratic }}=26.26\right)$ is lower than that of students with mother's overprotective attitude and those with mother's authoritarian attitude $\left(\overline{\mathrm{X}}_{\text {authoritarian }}=34.09\right)$.

3.5 One-way ANOVA Results of the Psychological Well-Being and Smartphone Addiction Scores by Father's Parental Attitudes

Table 5 gives the results of the comparison of the psychological well-being and smartphone addiction scores based on father's parental attitudes.

Table 5. One-way ANOVA results of the psychological well-being and smartphone addiction scores by father's parental attitudes

\begin{tabular}{llllllll}
\hline & Source of & SS & df & MS & F & p & $\begin{array}{l}\text { Significant } \\
\text { Scheffe's Test }\end{array}$ \\
& Variance & & & & Difference \\
Psychological & Between Groups & 1010.66 & 3 & 336.89 & 5.05 & $0.00^{*}$ & Indifferent -overprotective \\
Well-being & Within Groups & 26930.86 & 404 & 66.66 & & & Indifferent -democratic \\
& Total & 27941.52 & 407 & & & & \\
\hline \multirow{2}{*}{$\begin{array}{l}\text { Smartphone } \\
\text { Addiction }\end{array}$} & Between Groups & 118.25 & 3 & 39.42 & 0.34 & 0.80 & \\
& Within Groups & 47125.00 & 404 & 116.65 & & & \\
& Total & 47243.26 & 407 & & & & \\
\hline
\end{tabular}

$* \mathrm{p}<.01$

As seen in Table 5, the students' mean score of psychological well-being significantly differ by their fathers' parental attitude $\left[\mathrm{F}_{(3 ; 407)}=5.05 ; \mathrm{p}<0.05\right]$. Scheffe's test indicates that the mean psychological well-being score of students with father's indifferent attitude $\left(\overline{\mathrm{X}}_{\text {indifferent }}=37.71\right)$ is lower than that of students with father's overprotective attitude $\left(\overline{\mathrm{X}}_{\text {protective }}=42.72\right)$ and those with father's democratic attitude $\left(\overline{\mathrm{X}}_{\text {democratic }}=43.18\right)$. However, there is no statistically significant difference in the students' mean score of smartphone addiction by their fathers' parental attitudes $\left(\mathrm{F}_{(3 ; 407)}=0.34 ; \mathrm{p}>0.05\right)$. 
3.6 One-way ANOVA Results of the Psychological Well-Being and Smartphone Addiction Scores by Students' Academic Achievement Level

Table 6 shows the results of the comparison of the psychological well-being and smartphone addiction scores based on students' academic achievement level.

Table 6. One-way ANOVA results of the psychological well-being and smartphone addiction scores by students' academic achievement level

\begin{tabular}{llllllll}
\hline & $\begin{array}{l}\text { Source of } \\
\text { Variance }\end{array}$ & SS & df & MS & F & p $\begin{array}{l}\text { Significant Difference } \\
\text { Scheffe's Test }\end{array}$ \\
\hline Psychological & Between Groups & 31.08 & 2 & 15.54 & 0.23 & 0.80 & ----------- \\
Well-being & Within Groups & 27895.97 & 404 & 69.05 & & & \\
& Total & 27927.05 & 406 & & & & \\
\hline Smartphone & Between Groups & 393.16 & 2 & 196.58 & 1.70 & 0.19 & ---------- \\
Addiction & Within Groups & 46810.63 & 404 & 115.87 & & & \\
& Total & 47203.79 & 406 & & & & \\
\hline
\end{tabular}

As seen in Table 6, there is no statistically significant difference in the students' mean score of psychological well-being $\left[\mathrm{F}_{(2 ; 406)}=0.23 ; \mathrm{p}>0.05\right]$ and in their mean score of smartphone addiction $\left[\mathrm{F}_{(2 ; 406)}=1.70 ; \mathrm{p}>0.05\right]$ based on their perceived academic achievement level.

3.7 One-way ANOVA Results of the Psychological Well-Being and Smartphone Addiction Scores by Family Economic Status

Table 7 gives the results of the comparison of the psychological well-being and smartphone addiction scores based on family economic status.

Table 7. One-way ANOVA results of the psychological well-being and smartphone addiction scores by family economic status

\begin{tabular}{llllllll}
\hline & Source of & SS & df & MS & F & p & $\begin{array}{l}\text { Significant Difference } \\
\text { Scheffe's Test }\end{array}$ \\
\hline Variance & Between Groups & 978.24 & 4 & 244.56 & 3.65 & $0.01 *$ Very low-low \\
Psychological & Within Groups & 26963.28 & 403 & 66.91 & & & Very low -moderate \\
Well-being & Total & 27941.52 & 407 & & & & Very low -good \\
\hline Smartphone & Between Groups & 689.92 & 4 & 172.48 & 1.49 & 0.20 & -------- \\
Addiction & Within Groups & 46553.33 & 403 & 115.52 & & & \\
& Total & 47243.26 & 407 & & & & \\
\hline
\end{tabular}

There is a statistically significant difference in the students' mean score of psychological well-being based on their perceived family economic status $\left[\mathrm{F}_{(4 ; 407)}=3.65 ; \mathrm{p}<0.05\right]$. According to Scheffe's test, the mean psychological well-being scores of students perceiving their family economic status 'very low' $\left(\overline{\mathrm{X}}_{\text {verv low }}=27.75\right)$ is lower than that of students perceiving their family economic status 'low' $\left(\overline{\mathrm{X}}_{\text {low }}=41.81\right)$, 'moderate' $\left(\overline{\mathrm{X}}_{\text {moderate }}=41.96\right)$, and high $(\overline{\mathrm{X}}$ high $=43.08$ ). However, there is no statistically significant difference in the students' mean score of smartphone addiction based on their perceived family economic status $\left(\mathrm{F}_{(3 ; 407)}=1.49 ; \mathrm{p}>0.05\right)$. 
3.8 Pearson Product Moment Correlation Analysis Results of the Relationship between the Students' Scores of Psychological Well-being and Smartphone Addiction

Table 8 gives the Pearson Product Moment Correlation analysis results of the relationship between psychological well-being and smartphone addiction of university students.

Table 8. Pearson Product Moment Correlation analysis results of the relationship between the students' scores of psychological well-being and smartphone addiction

\begin{tabular}{lll}
\hline & & Smartphone Addiction \\
\hline Psychological & Pearson Correlation (r) & $-0,25$ \\
well-being & $\mathrm{p}$ & 0,00 \\
& $\mathrm{~N}$ & 408
\end{tabular}

As seen in Table 8, there is a low significant negative correlation between two variables. In other words, while the psychological well-being scores rise, the smartphone addiction scores decreases.

\section{Discussion}

The present study attempted to investigate the psychological well-being and smartphone addiction levels of the students of the faculty of education in terms of the variables including gender, grade level, parental attitudes, academic achievement, and family economic status and to reveal the relationship between psychological well-being and smartphone addiction.

A statistically significant difference was found between male and female university students in terms of psychological well-being, and the psychological well-being level of female students was higher than that of male students. Based on the literature review, there is also a significant relation between psychological well-being and gender in the age groups of 14 to 17 and 19 to 25 (Eryılmaz \& Ercan, 2011), the psychological well-being level of women is higher than that of men, and it is associated with the fact that being a woman supports psychological well-being (Korkmaz, 2012; Yılmaz, 2014; Cooper et al., 1995; Özen \& Gülaçt1, 2012; Topuz, 2013). However, a study reported that the psychological well-being level of men was higher than that of women (Güven, 2008). There are also several studies suggesting that there is no significant difference in the psychological well-being of students by gender (Timur, 2008; Osmanoğlu \& Kaya, 2013; Tuzgöl, 2004; Özen, 2005; İlhan, 2005; Cihangir-Çankaya, 2009; Canbay, 2010; Uçan \& Kıran-Esen, 2015). There are a variety of studies that support and do not support the results of the present study. Thus, it seems that gender, alone, does not have an apparent effect on psychological well-being, and the effect of gender may be significant or insignificant in different studies.

In the present study, smartphone addiction did not show a significant difference by gender. On the one hand, Ünal (2015) also suggested that smartphone addiction did not differ by gender and the addiction levels were similar in both genders, on the other hand, the smartphone usage levels of female students were found to be significantly higher than those of male students (Doğan \& Tosun, 2016; Kwon et al., 2013). Considering the smartphone usage based on gender, another study reported that men were much more likely to use smartphones than women. Thus, the results of the present study seem to be supported by those of other studies.

No significant difference was found in the students' mean scores on the Psychological Well-Being Scale based on grade level. In other words, the psychological well-being levels of $1^{\text {st }}, 2^{\text {nd }}, 3^{\text {rd }}$, and $4^{\text {th }}$ grade students are similar. Osmanoğlu and Kaya (2013) also concluded that there was no statistically significant difference in the mean psychological well-being scores in terms of grade level. University students, on the one hand, maintain their studies, on the other hand, are engaged in a pursuit of a proper identity. Thus, psychological well-being levels tend to be similar between different grades.

In the present study, the mean smartphone addiction scores of the students significantly differed by grade level. The mean score of $1^{\text {st }}$ graders was higher than that of $3^{\text {rd }}$ and $4^{\text {th }}$ graders. In other saying, as the grade level increases, the addiction level decreases. Yilmaz et al. (2015) found out that the problematic use of mobile phones by high school students significantly differed by grade and the mean score of problematic use of mobile phones was higher in $12^{\text {th }}$ graders than in $9^{\text {th }}$ graders. The result of the present study is not in parallel with the literature. University students have to leave their family and friends, perhaps for the first time and get used to a new environment. During this period, they are expected to not only succeed but also orient themselves in their new environment (Wise \& King, 2008). From this point of view, it is assumed, based on the study finding, that students, in the early years of university life, lean towards virtual platforms where they can get rid of loneliness and establish good communication. 
The present study also found a significant difference the students' mean scores on the Psychological Well-Being Scale based on their mother's attitude. Accordingly, the mean psychological well-being score of those who perceived their mother's attitude as indifferent was found to be higher than that of those who perceived their mother's attitude as protective and democratic. On the other hand, the mean psychological well-being score of those who perceived their father's attitude as indifferent was found to be lower than that of those who perceived their father's attitude as protective and democratic. From the early childhood, children need environmental support, especially, parental support and guidance. In this way, they can be engaged in a healthy personal development and feel autonomous (Ryan \& Deci 2000; Morsünbül, 2011). There are acceptance, care, and love in protective and democratic parental attitude.

Father holds an extremely important place in a child's life. Father represents the outside world, power, and authority (Yildiz, 2004). These findings are significant as they stress the effect of parental attitudes on the psychological well-being level of young persons. However, it is a thought-provoking result that the psychological well-being level of the students who perceived their mother's attitude as indifferent was higher than that of those who perceived their mother's attitude as protective and democratic. In fact, there is no control in indifferent parental style. Parents remain indifferent to the needs of their child. Both awareness and acceptance and demand and control mechanisms are low. There is apparent negligence toward the child (Karaköse \& Karaköse, 2007). Thus, it is safe to say that parental attitudes have major importance in the psychologically healthy development and psychological well-being of students.

Considering the mean smartphone addiction scores of the students based on their mother's attitude, the smartphone addiction levels of those who perceived their mother's attitude as authoritarian and protective was higher than that of those who perceived their mother's attitude as democratic. This result is also significant as it emphasizes the importance of mother's attitude on child behavior. However, no significant difference was found in the students' mean scores on the Smartphone Addiction Scale based on father's attitude. No research supporting or not supporting this result was found in the literature.

No significant difference was found in the mean psychological well-being scores of the students based on academic achievement. However, there are research findings indicating that there is a positive relation between academic achievement and psychological well-being (Özen, 2005; Certel et al., 2015; Karakoç et al., 2013). Thus, the result of the present study is not in parallel with the literature. Similarly, there was no significant difference in the smartphone addiction levels of the students based on perceived academic achievement. In the present study, the variable of academic achievement was considered as student's self-perception. If academic achievement had been considered as the passing mark, the results would possibly have been different.

The psychological well-being level of the students significantly differed by their perception of family economic status. The mean psychological well-being score of those who perceived their family economic status as 'very low' was lower than that of those who perceived their family economic status as 'low', 'moderate', and 'high'. In other saying, as the perceived economic status increases, so does the psychological well-being level. Considering this result, in the light of the literature, there is a positive relation between a person's socioeconomic status and individual development. With the possibilities provided by an increase in income, it also leads to an increased level of happiness. The satisfaction level of needs is directly associated with the level of wellness and psychological well-being is influenced by the specific needs met (Tatlllığlu, 2015). Similarly, perceived economic status has a determining role in a person's quality of life (Koçoğlu \& Akın, 2009), and the psychological well-being level of students with a "high" and "moderate" economic status is significantly higher that of those with a "low" economic status (Özen, 2005). Sayar (2006) also suggested that students with a low socioeconomic status had a significantly reduced level of psychological adjustment but increased depressive symptoms. As the spending capacity of people is regarded as a resource to help them reach their individual objectives, it seems to be a significant predictor of psychological well-being (Göcen, 2013). Based on the result of the present study and other studies in the literature, perceived economic status has an influence on psychological well-being.

No significant difference was found in the mean smartphone addiction scores of the students by family economic status. However, it has been argued that as the level of family income increases so does the level of smartphone addiction (Ünal, 2015; Nielsen, 2012). Thus, the result of the present study is not in parallel with the literature.

Based on the results of the correlation analysis, there is a significant negative correlation between psychological well-being and smartphone addiction. Thus, while the students' scores of psychological well-being increases, their scores of smartphone addiction decreases. In other words, smartphone addiction tends to decrease in the case of an increased level of psychological well-being. As it is known, university students need help for a variety of issues 
such as separation from family, adapting to a new environment, economic difficulties, and challenges associated with romantic relationships (Baş et al., 2016). However, students who cannot find sufficient psychological support from their environment may often feel lonely, depressed or weak and embark on a quest to fill the void. Thus, it leads to smartphone addiction.

\section{Conclusion and Recommendations}

The relationship between university students' levels of psychological well-being and smartphone addiction seems to be significant based on this research. Factors affecting university students' levels of psychological well-being and smartphone addiction include gender, grade, parental attitudes, economic status of the family, and level of perception. In this context, the following practical recommendations can be offered:

1. Training programs can be given in order to raise parents' awareness about the effect of parental attitudes on the psychological well-being of students.

2. As psychological well-being levels of economically powerful students also rise, students should be economically supported.

3. Individual or group counseling can be offered to help students develop positive thinking and to support their psychological well-being.

4. Training can be offered to students of all grades in order to raise awareness of the conscious use of smartphones.

5. University freshmen can be motivated to join in social activities and student clubs in order to help them socialize, make friends and develop their communication skills.

\subsection{Recommendations for Future Research}

In light of the results of the present study, the following recommendations can be offered to educationists and researchers:

1. Similar studies in different sample groups can be conducted in order to generalize the findings of the research.

2. Smartphone addiction and psychological well-being can be investigated based on different variables.

3. Training can be given in order to develop communication skills and social relationships, and then the effect on such trainings on psychological well-being smartphone addiction can be investigated.

4. Comparative studies can be carried out to evaluate the relationship between psychological well-being and smartphone addiction of students studying at different faculties of universities.

\section{References}

Adriana, B., \& James, G. P. (2005). Psychological predictors of problem mobile phone use. Cyberpsychology \& Behavior, 8(1), 39-51. http://dx.doi.org/10.1089/cpb.2005.8.39

Akın, A. (2008). Scales of psychological well-being: a study of validity and reliability. Educational Science: Theory And Practice, 8(3), 721-750.

Akın, A. (2009). Akılcı duygusal davranış̧̧ terapi (SDDT) odaklı grupla psikolojik danışmanın psikolojik iyi olma ve öz-duyarlı üzerindeki etkisi. (Doktora tezi, Sakarya Üniversitesi Sosyal Bilimler Enstitüsü, Sakarya). https://tez2.yok.gov.tr adresinden edinilmiştir.

Akın E., Divanoğlu S. (2009) Üniversite öğrencilerinin cep telefonu kullanımına karşı genel tutumları ve bu tutumların, kullanıma yansımalarına yönelik Aksaray Üniversitesi’nde bir araştırma. SÜ İBF Sosyal ve Ekonomik Araştırmalar Dergisi, 17, 69-93.

Baş-U.A., Soysal-Öz, F.S., \& Aysan, F. (2016). Üniversite öğrencilerinde problemli internet kullanımının psikolojik iyi-oluş ve sosyal destek ile ilişkisi. Insan ve Toplum Bilimleri Araştırmalarl Dergisi, 5(4), 1035-1046. http://dx.doi.org/10.15869/itobiad.85603

Bianchi A, Phillips J.G. (2005). Psychological predictors of problem mobile phone use. Journal of Cyberpsychology \& Behavior, 8(1), 39-51. http://dx.doi.org/10.1089/cpb.2005.8.39

Canbay, H. (2010). Lise öğrencilerinin öznel iyi oluş düzeyleri ile sosyal beceri düzeyleri arasindaki ilişskinin incelenmesi.(Yüksek lisans tezi, Dokuz Eylül üniversitesi Eğitim Bilimleri Enstitüsü, İzmir). https://tez2.yok.gov.tr adresinden edinilmiştir.

CCWTR. (2012). Her 4 Türk gencinden 3'ü akıllı telefon bağımlısı. http://www.btnet.com.tr/yasam-tarzi/her-4-turk-gencinden-3-u-akilli-telefon-bagimlisi/1/14188, 16.06.2016. 
Certel Z., Bahadır Z., Saracaloğlu A.S., \& Varol R. (2015) Lise öğrencilerinin öz-yeterlikleri ile öznel iyi oluş düzeyleri arasındaki ilişkinin incelenmesi. Eğitim ve Öğretim Araştırmaları Dergisi, 4(2), 307-318.

Chen Y.F., \& Katz J. (2009). Extending family to school life: college students use of the mobile phone. Human-Computer Studies, 67, 179-191. http://dx.doi.org/10.1016/j.ijhcs.2008.09.002

Cihangir-Çankaya, Z. (2005). Öz-belirleme modeli: özerklik desteği, ihtiyaç doyumu, iyi olma. Yayımlanmamış doktora tezi, Gazi Ünivesitesi, Ankara.

Cooper, H., Okamura, L., \& McNeil, P. (1995). Situation and personality correlates of psychological well-being: Social activity and personal control. Journal of Research in Personality, 29, 395-417. http://dx.doi.org/10.1006/jrpe.1995.1023

Çetin, F.H., Pamuk, M., \& Donmuş, V. (2015). Ergenlerde problemli cep telefonu kullanımı ile akademik erteleme arasındaki ilişkide internet bağımlılığının aracılık rolünün incelenmesi. Çocuk ve Gençlik Ruh Sağlı̆̆ Dergisi, $22(1), 60-61$.

Çalışkan-Ülkü E., \& Demir, M.K. (2013). Kitle iletişim araçlarının öğrencilerin sınıf içi davranışlarına etkisi. The Journal of Academic Social Science Studies, 6(1), 587-608.

Çeçen, A.R., \& Cenkseven, F. (2007). Üniversite öğrencilerinde yalnızlığın yordayıcısı olarak psikolojik iyi olma. Ç.Ü. Sosyal Bilimler Enstitüsü Dergisi, 16(2), 109-118.

Doğan, U., \& Karakuş, Y. (2016). Lise Öğrencilerinin sosyal ağ siteleri kullanımının yordayıcısı olarak çok boyutlu yalnılık. Sakarya Üniversitesi Journal of Education, 6(1), 57-71. http://dx.doi.org/10.19126/suje.40198

Doğan, U., \& Tosun, İ.N. (2016). Lise öğrencilerinde problemli akıllı telefon kullanımının sosyal kaygı ve sosyal ağların kullanımına aracılık etkisi. Adlyaman Üniversitesi Sosyal Bilimler Enstitüsü Dergisi, 8(22), 99-128. http://dx.doi.org/10.14520/adyusbd.66762

Diener, E., Oishi, S., Lucas, R.E. (2003). Personality, culture, and subjective well-being. Annual Review of Psychology, 54, 403-425. http://dx.doi.org/10.1146/annurev.psych.54.101601.145056

Diener, E., Wirtz, D., Tov, W., Kim-Prieto, C., Choi, D., Oishi, S., \& Biswas-Diener, R. (2010). New well-being measures: Short scales to assess flourishing and positive and negative feelings. Social Indicators Research, 97, 143-156. http://dx.doi.org/10.1007/s11205-009-9493-y

Eryılmaz, A. (2010). Ergenlerde öznel iyi oluşu artırma stratejilerini kullanma ile akademik motivasyon arasındaki ilişki. Klinik Psikiyatri, 13, 77- 84.

Eryılmaz, A. ve Ercan, L. (2011). Öznel iyi oluşun cinsiyet, yaş grupları ve kişilik özellikleri açısından incelenmesi. Türk Psikolojik Danışma ve Rehberlik Dergisi, 4(36), 139-151.

Grant, J.E., Potenza, M.N., Weinstein, A., \& Gorelick, D.A. (2010). Introduction to behavioral addictions. The American journal of drug and alcohol abuse, 36(5), 233-41. http://dx.doi.org/10.3109/00952990.2010.491884

Göcen, G. (2013). Pozitif psikoloji düzleminde psikolojik iyi olma ve dini yönelim ilişkisi: yetişkinler üzerine bir araştırma. Toplum Bilimleri Dergisi, 7(13), 97-130.

Gümüș, İ., \& Örgev, C. (2015). Önlisans öğrencilerinin akıllı cep telefon kullanmalarının başarı ve harcama düzeylerine olası etkileri üzerine bir çalışma. ISCAT/Akademik Platform, 310-315. http://kritik-analitik.com/ISCAT2015_bildiriler/C1-ISCAT2015ID65.pdf

Güven, H., (2008). Depresyon ve dindarlık ilişkisi. (Yüksek lisans tezi, Marmara Üniversitesi Sosyal Bilimler Enstitüsü, İstanbul). https://tez2.yok.gov.tr adresinden edinilmiştir.

İlhan, T. (2005). Öznel iyi oluşa dayalı mizah tarzları modeli. (Yüksek lisans tezi, Gazi Üniversitesi Eğitim Bilimleri Enstitüsü, Ankara). https://tez2.yok.gov.tr adresinden edinilmiştir.

Karakoç, A., Bingöl, F., \& Karaca, S. (2013). Lise öğrencilerinde ergen öznel iyi oluş ile olumlu gelecek beklentisi arasındaki ilişkinin incelenmesi. Uluslararası Hakemli Akademik Spor Sağllk ve Tıp Bilimleri Dergisi, 6(3), 43-50.

Karaaslan, A.İ., \& Budak, L. (2012). Üniversite öğrencilerinin cep telefonu özelliklerini kullanımlarının ve gündelik iletişimlerine etkisinin araştırılması. Journal of Yaşar University, 26(7), 4548 - 4571.

Karaköse, Ş., \& Karaköse, R. (2007).Çocuk eğitiminde babanın rolü. İstanbul: Yakamoz Yayıncılık. Kesgin, C., \& Topuzoğlu, A. (2006). Sağlığın tanımı; başa çıkma. İstanbul Kültür Üniversitesi Dergisi, 3, 47-49. 
Koçoğlu, D., \& Akın, B. (2009). Sosyo-ekonomik eşitsizliklerin sağlıklı yaşam biçimi davranışları ve yaşam kalitesi ile ilişkisi, Dokuz Eylül Üniversitesi Hemşirelik Yüksekokulu Elektronik Dergisi, 2(4), 145-154.

Korkmaz, E.N. (2012). Tanr1'ya bağlanma ve psikolojik iyi olma. Toplum Bilimleri Dergisi, 6(12), 95-112.

Kwon, M., Kim, D.J., Cho, H., \& Yang, S. (2013) The smartphone addiction scale: development and validation of a short version for adolescents. PloS one, 8:e56936. http://dx.doi.org/10.1371/journal.pone.0083558

Morsünbül, Ü. (2011). Ergenlikte özerkliğin ve kimlik biçimlenmesinin öznel iyi oluş üzerindeki etkisi. (Doktora tezi, Ankara Üniversitesi Eğitim Bilimleri Enstitüsü, Ankara). https://tez2.yok.gov.tr adresinden edinilmiştir.

Nielsen (2012). Survey new U.S. smartphone growth by age and income. http://www.nielsen.com/us/en/insights/news/2012/survey-new-u-s smartphone-growth-by-age-and-income.html, 18.08.2016.

Noyan, C.O., Enez, D.A., Nurmedov, S., Yılmaz, O., \& Dilbaz N. (2015). Akıllı telefon bağımlılığı ölçeğinin kısa formunun üniversite öğrencilerinde Türkçe geçerlilik ve güvenilirlik çalışması. Anadolu Psikiyatri Dergisi, 16(1), 73-81.

Osmanoğlu, D.E., \& Kaya, H.İ. (2013). Öğretmen adaylarının yükseköğretime dair memnuniyet durumları ile öznel iyi oluş durumlarının değerlendirilmesi: Kafkas Üniversitesi örneği. Sosyal Bilimler Enstitüsü Dergisi, 12, 45-70.

Özen, Ö. (2005). Ergenlerin öznel iyi oluş düzeyleri. (Yüksek lisans tezi, Hacettepe Üniversitesi Sosyal Bilimler Enstitüsü, Ankara).https://tez2.yok.gov.tr adresinden edinilmiştir.

Özen, Y., \& Gülaçtı, F. (2012) Öğretmen adaylarının sosyal beceri ve psikolojik iyi oluş düzeylerinin incelenmesi. Uluslararası Hakemli Beşeri ve Akademik Bilimler Dergisi, 1(1), 83-101. http://dx.doi.org/10.17368/uhbab.2012018729

Öztürk, O. (2011). Ruh sağllğı ve bozuklukları. İstanbul: Nobel Tıp kitabevi.

Ryan, R. M., \& Deci, E.L. (2000). Intrinsic and extrinsic motivations: Classic definitions and new directions. Contemporary Educational Psychology, 25, 54-67. http://dx.doi.org/10.1006/ceps.1999.1020

Ryff, C.D. (1989). Happiness is everything or is it? Explorations on the meaning of psychological well-being. Journal of Personality and Social Psychology, 57(6), 1069-1081. http://dx.doi.org/10.1037/0022-3514.57.6.1069

Sarıkaya, A. (2015). 14-18 yaş arası ergenlerin benlik saygısı ve psikolojik dayanıklllık düzeyleri arasındaki ilişki.(Yüksek lisans tezi, İstanbul Bilim Üniversitesi Sosyal Bilimler Enstitüsü, İstanbul). https://tez2.yok.gov.tr adresinden edinilmiştir.

Sayar, M. (2006). Düşük sosyo-ekonomik düzeyden gelen ergenlerin algıladıkları sosyal destek ile ruh sağllkları arasındaki iliş̧ki üzerine boylamsal bir çalışma. (Yüksek lisans tezi, Boğaziçi Üniversitesi Sosyal Bilimler Enstitüsü, İstanbul). https://tez2.yok.gov.tr adresinden edinilmiştir.

Saygın, Y., \& Arslan, C. (2009). Üniversite öğrencilerinin sosyal destek, benlik saygısı ve öznel iyi oluş düzeylerinin incelenmesi. Selçuk Üniversitesi Ahmet Keleşoğlu Eğitim Fakültesi, 28, 207-222.

Seligman, M.P.E., \& Csikszenmihalyi, M. (2000). Positive psychology. American Psychologist, 53, 3-14.

Şar, A.H. (2013). Ergenlerde yalnızlık ile mobil telefon bağimlılığı probleminin bazı değişkenler açısından incelenmesi. The Journal of Academic Social Sience Studies, 6(2), 1207-1220.

Şenyuva, D. (2016). Gençler Akıllı Telefon Bağımlısı. http://sosyalmedya.co/gencler-akıllı-telefon-bagimlisi, 16.06.2016.

Tatlı, H. (2015). Akıllı telefon seçiminin belirleyicileri: üniversite öğrencileri üzerine bir Uygulama. Çanktrı Karatekin Üniversitesi İktisadi ve İdari Bilimler Fakültesi Dergisi, 1-19. http://dx.doi.org/10.18074/cnuiibf.233

Tatlılığlu, K. (2015). Üniversite öğrencilerinin aylık gelir ve harcama düzeyi ile psikolojik iyi oluşları arasındaki ilişkinin incelenmesi: Bingöl Üniversitesi Örneği. Elektronik Sosyal Bilimler Dergisi, 14(55), 1-15. http://dx.doi.org/10.17755/esosder.40308

Telef , B.B. (2013). Psikolojik iyi oluş ölçeği: Türkçeye uyarlama, geçerlik ve güvenirlik çalışması. Hacettepe Üniversitesi Ë̆itim Fakültesi Dergisi, 28(3), 374-384. 
Timur M.S. (2008). Boşanma sürecinde olan ve olmayan evli bireylerin psikolojik iyi oluş düzeylerini etkileyen faktörlerin incelenmesi. (Yüksek lisans tezi, Ankara Üniversitesi Eğitim Bilimleri Enstitüsü, Ankara). https://tez2.yok.gov.tr adresinden edinilmiştir.

Topuz, C. (2013). Üniversite öğrencilerinde özgeciliğin öznel iyi oluş ve psikolojik iyi oluş ile ilişkisinin incelenmesi. (Yüksek lisans tezi, Fatih Üniversitesi Sosyal Bilimler Enstitüsü, İstanbul). https://tez2.yok.gov.tr adresinden edinilmiştir.

Tuzgöl -Dost, M. (2004). Üniversite ögrrencilerinin öznel iyi oluş düzeyleri. (Doktora tezi, Hacettepe Üniversitesi Sosyal Bilimler Enstitüsü, Ankara). https://tez2.yok.gov.tr adresinden edinilmiştir.

Türkiye İstatistik Kurumu (TUIK), (2015). Hanehalkı Bilişim Teknolojileri Kullanım Araştırması. http://www.tuik.gov.tr, 15.06.2016.

Tütüncü, M. (2012). Yönetici ve çalışanların psikolojik iyi olma ve stres düzeyleri açısından karşılaştırılması. (Yüksek lisans tezi, Maltepe Üniversitesi Sosyal Bilimler Enstitüsü, İstanbul). https://tez2.yok.gov.tr adresinden edinilmiştir..

Uçan, A., \& Kıran-Esen B. (2015). Ergenlerin öznel iyi oluşlarının toplumsal konum ile ilgili risk alma değişkenine göre incelenmesi. Mersin Üniversitesi Eğitim Fakültesi Dergisi, 11(2), 288-299. http://dx.doi.org/10.17860/efd.22192

Ünal, H.M. (2015). Ankara Yıldırım Beyazıt Üniversitesi Tıp Fakültesi öğrencilerinin akıllı telefon bağımlılık düzeylerinin belirlenmesi.(Uzmanlık tezi, Yıldırım Beyazıt Üniversitesi Tıp Fakültesi Aile Hekimliği Anabilim Dal1, Ankara). https://tez2.yok.gov.tr adresinden edinilmiştir.

Wise, R. A., \& King, A. R. (2008). Family environment as a predictor of the college students' friendships. Journal of Family Issues, 29, 828-848. http://dx.doi.org/10.1177/0192513X07309461

Yıldız, A.S. (2004).Ebeveyn tutumları ve saldırganlık. Polis Bilimleri Dergisi, 6(3-4), 131-149.

Yılmaz, M.F. (2013). Üniversite öğrencilerinin psikolojik iyi oluşlarının problemli internet kullanımı ve bazı demografik değişkenler açısından incelenmesi. (Yüksek lisans tezi, Anadolu Üniversitesi Eğitim Bilimleri Enstitüsü, Eskişehir). https://tez2.yok.gov.tr adresinden edinilmiştir.

Yılmaz, G., Şar, A.H., \& Civan, S. (2015). Ergenlerde mobil telefon bağımlığı ile sosyal kaygı arasındaki ilişkinin incelenmesi. Online Journal of Technology Addiction \& Cyberbullying, 2(2), 20-37. 